\title{
Stage IV Thyroid Gland Medullary Carcinoma AJCC v8
}

National Cancer Institute

\section{Source}

National Cancer Institute. Stage IV Thyroid Gland Medullary Carcinoma A/CC v8. NCI

Thesaurus. Code C141046.

Stage IV includes: IVA: (T 4a, Any N, M0); (T1-3, N1b, M0); IVB: (T 4b, Any N, M0); IVC: (Any T, Any N, M1). T1: Tumor measuring $2 \mathrm{~cm}$ or less in greatest dimension limited to the thyroid. T2: Tumor measuring more than $2 \mathrm{~cm}$ but less than $4 \mathrm{~cm}$ in greatest dimension limited to the thyroid. T3: Tumor measuring $4 \mathrm{~cm}$ or more in greatest dimension or with extrathyroidal extension. T4a: Moderately advanced disease; tumor of any size with gross extrathyroidal extension into the nearby tissues of the neck, including subcutaneous soft tissue, larynx, trachea, esophagus, or recurrent laryngeal nerve. T4b: Very advanced disease; tumor of any size with extension towards the spine or into nearby large blood vessels, invading the prevertebral fascia, or encasing the carotid artery or mediastinal vessels. N1b: Metastasis to unilateral, bilateral, or contralateral lateral neck lymph nodes levels I, II, III, IV, or V or retropharyng eal lymph nodes. M0: No distant metastasis. M1: Distant metastasis. (from AJCC 8th Ed.) 